\title{
Enhancing the Transition Capability of Danish Biomass Technology By Applying a Futures Study Backcasting Methodology on the Biogas Sector.
}

\author{
Rikke Lybæk ${ }^{1}$, Thomas Budde Christensen and Tyge Kjær
}

\begin{abstract}
This paper discusses how the Danish biogas sector can achieve the political goals set out by the Danish government, in order to turn around the currently weak implementation of the technology. Biogas technology provides many environmental and energy related benefits, but the transition capability of the technology has so far not been supported by a stable policy pushing the sector in the right direction. The paper argues that a more holistic and consistent support for the biogas sector must be developed, enhancing its independence from shifting Danish policy regimes. This could be achieved by applying a backcasting methodology in combination with future research activities which are identified by means of energy chain analysis. The paper stresses that future Danish biogas research should be applied all along the sector's energy chain, and not just in parts of it, looking at enhancement of the transition capability within 'Resources', 'Technology/Conversion' and 'Distribution/End-use'. The future research activities, proposed in this paper are interconnected and thought backwards with the goal of creating reachable aims for achieving the political targets set forth before the year 2020 and 2050 .
\end{abstract}

Keywords : Renewable energy, transition technology, biogas, manure, backcasting, energy chain.

\section{Introduction}

Denmark has 24 large scale centralized biogas plants in operation today, each having a total capacity of 50-600 $\mathrm{m}^{3}$ manure per day, and 60 small scale farm plants with a capacity of $5-50 \mathrm{~m}^{3}$ manure per day. Biogas plants contribute to an energy production of $4 \mathrm{PJ}$ annually, corresponding to $0.5 \%$ of current Danish energy consumption (equals $800 \mathrm{PJ}$ ). The total available manure that could be digested is estimated to 40 PJ (Danish Government, 2009). This corresponds to $5 \%$ of the actual energy consumption if fully utilized. The political goals for the biogas sector in Denmark required, according to the Danish 'Energy Deal 2008', that by $202530 \%$ of the animal manure must be

| ${ }^{1}$ Department of Environmental, Social and Spatial Change (ENSPAC), University of Roskilde House 9.2, 4000 Roskilde, P.O. Box 260, Universitetsvej 1, Denmark 
digested, corresponding to 12 PJ (Danish Government, 2008). A year later, the Danish Government's 'Green Growth Strategy 2009' was launched, increasing the target for biogas by requiring $50 \%$ of the animal manure digested. That goal should be met before 2020 and would mean 20 PJ (Danish Government, 2009). See Figure 2 below.

Apart from the goals for biogas stated above, Denmark has a target of implementing $30 \%$ renewable energy before 2020 (Ministry of Climate and Energy, 2010), as well as a long term vision of having a carbon free energy sector before 2050 (Klimakommissionen, 2010). A total transition from today's use of primarily fossil fuels, like coal, oil and natural gas (close to $80 \%$ of the primary energy consumption in 2012) to renewable energy is envisioned within the next 35 to 40 years. Fossil fuels will hence be substituted by wind energy as the base load, where liquid biomass fuels (like syngas \& biogas etc.) especially will be utilized as support-fuels when wind conditions are unfavorable for electricity production. Other technologies besides wind, biomass and smart grid technologies will also be applied in this transition, e.g. solar, geothermal energy, heat pumps etc. (Ibid.).

Besides being an important future support-fuel supplementing fluctuating wind energy, the production of biogas is a beneficial way of reducing greenhouse gas emissions as the technology provides multiple advantages: it increases energy supply security by diversifying the supply of renewable energy, it is able to reduce negative environmental impacts from nitrogen leaching from agriculture, and it provides a high value fertilizer for farmers substituting expensive artificial products (Tybirk, 2012). It is therefore very important that Denmark seeks to utilize the available manure, in combination with new types of biomass resources for biogas production, and pursue the implementation of as many biogas plants as possible to fully exploit the benefits to be gained from this transition technology.

\subsection{Research question and working questions}

Given the present relatively slow rate of implementation of biogas technology, it is very unlikely that the targets mentioned above will be achieved in the near future unless there is a greater focus on biogas technology and the context in which it is used. 40 large centralized biogas plants would for instance have to be implemented within the next 12 years to achieve a threefold increase (to $12 \mathrm{PJ}$ ) of biogas production by 2025 (Wittrup, 2009). Hence, it is important that future research, and other supportive activities targeting the biogas sector take the technology in the right direction as far as its contribution to sustainable development and $\mathrm{CO}_{2}$ emission reductions are concerned; thus the transition capability of the biogas technology. Our main research question captures this 
problem: How can the renewable energy transition capability of the biogas sector be enhanced in order to more rapidly move towards a carbon free energy supply? It can, however, seem very unclear as to how political goals could be reached. It is difficult to establish which activities should be undertaken immediately and which in the long run if the technology is going to be adequate for meeting the overall goal of a carbon free energy supply in 2050. Thus, setting political targets should be supported by a plan of how to reach those targets. A first working question is therefore: how can we operationalize the political goals for biogas so that they become more concrete and enable us to meet the targets?

Several activities, or different focus areas, have characterized past research supporting the biogas technology. Since the late 1970's where the first Danish government supported program for biogas was initiated the technology has underlain many different policy regimes having different focuses (see Lybæk, Christensen, \& Kjær, 2013, for a thorough analysis of the Danish biogas programs from 1978 to 2009). Thus, during the 1970's focus was on energy security following the energy crisis, whereas in the 1980's the focus was related to reducing nitrogen leaching from agriculture, and in the late 1990's and 2000's the focus primarily shifted to the merging issues related to climate change policy, environmental protection and finally to agricultural policy related to farmer's income. The conclusions from the research mentioned above indicate that public policies are vital for the development of the technology; not only in terms of funding development programmes, but also when it comes to shaping the direction of the technological development. Thus a second working question is: How can we establish research into biogas technology which is supported by the government but not subject to changes due to shifting political regimes?

\section{Methodology and analytical framework}

This section answers the working questions by employing an analytical framework which will in turn provide the platform for answering the main research question.

\subsection{Backcasting}

'Backcasting' is a futures study technique in which one formulates visions about or targets for the future. Against that background part-targets are established the meeting of which is necessary if the main targets are to be achieved. The point of departure is the present situation. Backcasting was first introduced in Amory Lovin's 'soft energy path' analysis in the mid 1970's (see Lovins, 1976), but was developed and utilized by John B. Robinson in the 1980's (Robinson, 1982a). Robinson describes backcasting as follows: 
"The major distinguishing characteristics of backcasting analysis are the concern, not with likely energy futures, but bow desirable futures can be attained. It is thus explicitly normative, involving 'working backwards' from a particularly future end-point to the present to determine what policy measures would be required to reach that future" (Robinson, 1982a, p.337).

Backcasting was introduced as an alternative to the much used forecasting and scenario methods of analysis, both being projections, which rely on reflections of 'likely futures' or 'alternative futures' (see Figure 1 below). These projections have been criticized for their, at times, high degree of inaccuracy and for their inherently conservative bias. The need to base the projections on past tendencies and relations means that there is no legitimate technique to estimate the emergence of new variables (e.g. new renewable energy technologies or other technical advances etc.), as logically are not part of the past which the projections are built upon (Robinson, 1982b). This element of uncertainty can be weighed better when using backcasting, as it relies more on qualitative ways of thinking, as opposed to scenario techniques and computer models from predefined criteria and assumptions (Robinson, 2003).

Figure 1: Forecasting, Scenarios (projections) \& Backcasting Methodologies

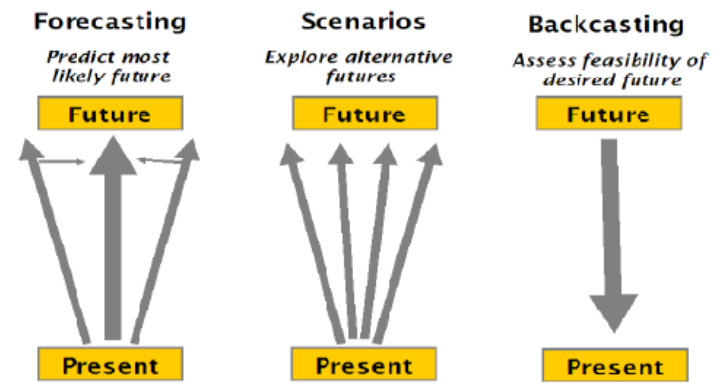

Source: Arising, 2009

Backcasting looks at a 'desired future' and works its way back to the present from the future. This means that we have an opportunity to work with desirable futures and not only with likely or alternative futures. In our backcasting of the biogas sector, we will first take our point of departure in the 2050 political vision of a carbon free energy supply, requiring a utilization of the total manure potential in Denmark, equal to 40 PJ applied before 2050. Next, the political target formulated for the year 2020, at which point digestion of $50 \%$ of the total manure should contribute $20 \mathrm{PJ}$, is chosen. These points of departure $(100 \%$ and $50 \%$ utilization of the manure before 2050 and 2020 respectively), will be fixed points for the backcasting of the Danish biogas sector in this paper. This is illustrated in Figure 2 below, showing the targets for biogas and the business as usual projections. 
Figure 2: Fix-points in the backcasting of biogas (nr. 3 \& 2)

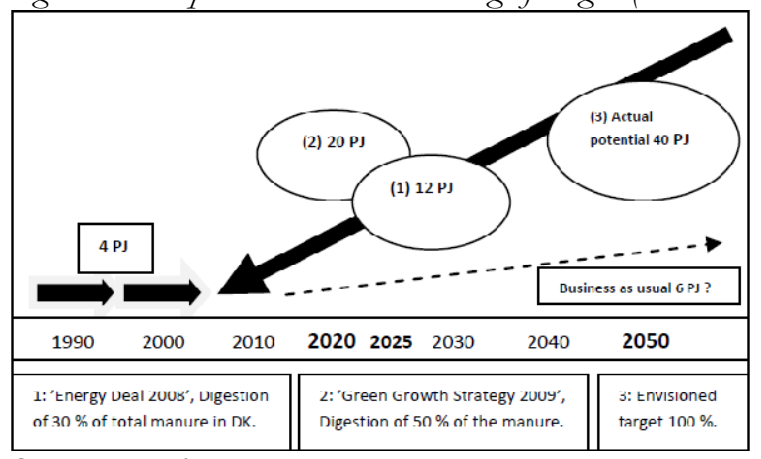

Source: Authors own

Thus, to answer the first working question, backcasting is found beneficial when operationalizing the shifting climate targets set down by the Danish government. By identifying fix-points for certain activities to be achieved, we will work 'backwards' and propose focus areas and research activities that should be supported politically. But in which context should we understand the Danish biogas sector? And which policy elements should be part of a backcasting strategy? This will be the focus of the following section.

\subsection{Energy Chain analysis}

To enhance the renewable energy transition capability of the biogas sector, we must understand the context in which the technology is situated. Thus, to be able to backcast biogas, as described above, we need to understand the sector in its specific context and use a concept that will help us understand how energy technologies and systems work. We will do that by looking at the 'energy chain' outlined in Figure 3 below:

Figure 3: Energy chain

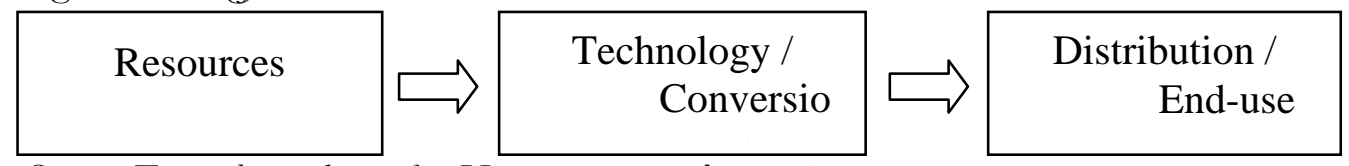

Source: Figure by authors after Hamamatse et. al., 2004

The energy chain takes its point of departure in an optimization of the chain as a whole, that is from the utilization of resources (manure and biomass), to conversion of these resources in the biogas technology, to distribution and final end-use of the produces energy, being biogas or power and heat. It is vital that a coordination of the activities in the energy chain is applied in order to achieve the highest benefits possible (Hamamatsu, Saikawa, \& Hashimoyo, 2004), 
exemplified by the following. 'Resources': Identification of substitutes to the scares industrial biomass waste, currently being used as gas boosters (easy digestible biomass substances providing high gas yield), is very important. Thus, utilizing additional and less competitive biomass will break down the gas booster supplybarrier currently hampering a further implementation of the technology. 'Technology/ Conversion': Applying such biomass in biogas technology with lower capital costs, extracting even more biogas due to enhanced operation practices, will generate surplus biogas reducing the investment risk caused by increased income from gas sale. 'Distribution/End-use': These initiatives could be more easily implemented by introducing activities which enhance the distribution and final end-use market for the sale of biogas, hence providing extra income for farmers and other investors. Thus, to answer the second working question, it is important that future research and other activities within the biogas sector relate to all aspects of the energy chain of the biogas sector (Hamamatsu et. al., 2004). Activities must thus not only focus on limited parts of the chain, e.g. the growing of energy crops for gas boosting originating from a policy regime focusing on agriculture and the creation of extra income for farmers. When applying activities all along the energy chain, a more holistic and consistent support for the biogas sector could develop, enhancing the independence of shifting policy regimes.

\subsection{Identification of important elements of the biogas energy chain} First we look at initiatives which require further research (long time period) and thus cannot be immediately implemented, but are nevertheless necessary in order to reach a $100 \%$ utilization of the manure in Denmark. Hereafter we look at activities that need emphasizing before 2020, being either a precondition for the 2050 activities or being more easily implementable (short time period). In general, however, we focus on activities which do not hamper the development of different future technology tracks, but on the contrary open up the possibility for different possible solutions. Other elements or activities than those described below could also be important in order to support the transition capability of the future Danish biogas sector. The activities exemplified are regarded as the most important for the development of the biogas sector based on branch interviews, plant visits and literature studies, as well as earlier works by the authors (see Lybæk, Christensen, \& Kjær, 2012 and 2013).

For biogas, Resources' primarily means manure, but there could be other types of less competitive organic biomass such as organic household waste or energy crops such as maize or beet etc. enhancing the gas yield. New types of energy crops or gas boosters should however be developed in the future, for example third generation biofuels, namely algae. In the long run, optimizations in the 
design of future stables providing better access to the animal manure would be desirable. Before that, improvements in the handling of manure in existing stables could relatively easily be applied, for example, by lowering the content of water in the manure etc. By applying such activities, additional digestible biomass could be utilized in Danish biogas plants and hence increase the gas production. Thus, the important elements that need focusing on in this part of the energy chain are energy crops and new stables (2050), and energy crops and manure handling (2020).

In the 'Technology/Conversion' part of the energy chain analysis, the actual means of producing biogas is emphasized. The efficient conversion of biomass has been pursued in Denmark by gradually implementing larger and larger biogas plants implying benefits of scale, also having the purpose of enhancing the economic feasibility of the plants. High capital costs connected with investments in biogas plants have implied that many plants are dependent on organic industrial biomass waste to boost gas production; now being a barrier due to shortage. Thus, in the long run it is necessary to develop more efficient and low cost biogas plants (turnkey concepts), and in the short term to apply changes in plant operation practices etc., providing higher gas yields. This will also reduce the pressure on the technology as far as adding gas boosters. Thus, important elements in this part of the chain will be to develop 'turnkey solutions' (2050) and in the short run to focus on 'extraction of additional gas' (2020) in order to optimize this part of the energy chain.

Distribution/End-use'. Using biogas for transportation purposes could increase its market. Vehicles running on biogas such as those in Sweden, could thus be used in Denmark, but will require some immediate infrastructure and vehicle changes etc. This could, however, increase market demand and hence strengthen the investment in the biogas technology by farmers, and other interested parties. Utilization of energy from biogas plants has, so far, however, been characterized as follows: on small farm biogas plants the generated heat is normally used for heating up the reactor tank, stables and farmhouse whereas the electricity is sold to the local electricity company. On large scale centralized biogas plants, a minor part of the heat is used for heating up reactor tanks, but the majority distributed on a local district heating network to nearby citizens, with electricity distributed on the local grid as for the smaller plants. Alternatively, the biogas can be distributed to a nearby Combined Heat and Power plant (CHP) for the production of electricity and heat and then distributed on a larger district heating system in the region. Thus, so far, the market for biogas has been relatively small, and primarily connected to local communities. New market opportunities could include using the natural gas pipelines in Denmark for biogas distribution, storage and mixing with natural gas. The use of biogas for transport depends on the implementation of the above, and would enhance the market opportunities 
even further. Thus, in this part of the energy chain, the activities 'biogas vehicles' (2050) and 'mixed gas' (2020) are selected as important for the technology's future transition capability.

\subsection{Analytical framework}

$\rightarrow$ The first backcasting of the biogas sector will take its point of departure in the target for 2050 of $100 \%$ utilization of the manure, focusing on the following element of the energy chain:

- Energy crops \& new stables (resources)

- Turnkey solutions (technology/conversion)

- Biogas vehicles (distribution/end-use)

$\rightarrow$ The second backcasting of the biogas sector is a precondition for the first, and takes its point of departure in the target for 2020,50\% utilization of the manure, focusing on the following elements of the energy chain:

- Energy crops \& manure handling (resources)

- Extraction of additional gas (technology/conversion)

- Mixed gas (distribution/end-use)

\section{Backcasting: $100 \%$ digestion of manure before 2050}

In the following two sections, we will briefly elaborate on the backcasted elements outlined above to be achieved before 2050 and 2020. These activities should be included and developed further as policy elements (Robinson, 1982a) to support a future Danish biogas research strategy.

\subsection{Energy crops ('Resources'; 2050)}

The use of maize and beet etc. for boosting the gas production of Danish biogas plants (see 4.1) competes with food for humans and animals. To fully utilize the manure potential, we thus suggest that alternatives should be developed in the long run. This could, for instance, be algae harvested from the sea, or cultivated on land in combination with for instance carbon capture used as growing nutrient. The potentials for growing algae are currently being researched, and could prove to be an important part of a carbon free energy supply in Denmark in the future. Several research projects have been established to gain knowledge about the energy potentials of algae (see AlgaeCenter Denmark). Experiments show that it is possible to produce around 45 tonnes of sea lettuce (macroalgae) annually in dry weight per hectare. It is more than twice as much as a conventional energy crops offers. One reason is that sea lettuce under optimal growth conditions with plenty of nutrients, for instance wastewater together with light radiation, can double its biomass in a day (AlgeCenter Danmark, 2012). 
Further research will, however, have to highlight the potentials for using algae for gas boosters in the future.

\subsection{New stables ('Resources'; 2050)}

In the long run new stables should be designed to enhance the options for separating manure, straw and solid waste to avoid mixing, and to facilitate a fast and efficient collection of the manure to limit methane losses (Tybirk, 2010). Stables built after the straw-flow principle could thus become a more widespread option before 2050. Such stables enable the pigs to collect straw from an automatic straw-installation when they need it (and thus establish a bed and use the straw for rooting in the 'dry area'), and when the straw is mixed with the solid waste it is automatically pushed down in the manure canals and thus transported further to the solid waste storage facility. The floor of the stable has a 7 degree slope enabling liquid waste (manure) to run down to the 'wet area' and be collected relatively quickly without being mixed with straw and solid waste (Lybæk \& Møller, 1999). Future agricultural policies should support the building of such stables in Denmark.

\subsection{Turnkey solutions ('Technology/Conversion'; 2050)}

Reduced capital costs: Today, the biogas technology is primarily implemented as customized solutions on individual farms, taking into account the specific demands and requirements present at the different sites (Lundsgaard, 2011). This is a business model which adds additional expenses to the biogas plants. More technical turnkey solutions must be available in the future if the goals for biogas are to be achieved. Lower capital costs will, if operational costs are not increased, also lower the requirements to the necessary gas production, and thus facilitate the plants to operate on manure alone or/and limited amounts of gas boosters. Turnkey suppliers deliver a fixed solution and coordinates design, tests, and production at upstream suppliers. The buyer of a biogas plant is, via the turnkey supplier, able to purchase a standardized solution, which has been tested and proven beforehand. Standardized components include piping systems, heat exchangers, pumps and other mechanical parts, storage tanks, reactor tanks and other components (Tafdrup, 2009). Thus, future policies revolving around technical concepts for biogas plants should support this development.

\subsection{Biogas vehicles ('Distribution/End-use'; 2050)}

Approximately 16,000 cars, several hundred buses and trucks, and one train, run on biogas in Sweden, and more than 150 service stations exist at which one can purchase biogas. To be used as a transport fuel, biogas has to be upgraded to at least $95 \%$ methane by volume and utilized in vehicles originally modified to 
operate on natural gas. In Denmark, it is not possible to purchase biogas for transportation purposes. It is important to focus on biogas fuelled vehicles as they reduce $\mathrm{CO}_{2}$ emissions by between $75 \%$ and $200 \%$ compared with fossil fuels. The higher figure is based on liquid manure and shows a negative $\mathrm{CO}_{2}$ contribution, which happens because liquid manure left untreated generates methane emissions that are 21 times more powerful as a greenhouse gas compared to $\mathrm{CO}_{2}$ (NSCA, 2006). Thus, policies to transform part of the Danish vehicles fleet (only heavy vehicles due to limited biogas resources) and to distribute biogas to service stations around the country, will have to be developed in the future in order to gain these benefits. This could be facilitated by a low cost scheme for upgrading biogas, and by using the existing natural gas network for distribution of the gas, mentioned later in this paper.

\section{Backcasting: $50 \%$ digestion of manure before 2020}

\subsection{Energy crops ('Resources'; 2020)}

As mentioned several times, it is important to identify less competitive substitutes to industrial biomass waste in order to support the further implementation of the biogas technology. This could include energy crops grown with this specific purpose, or grass from natural areas etc. It is estimated that 30 PJ can be produced from biomass produced on approximately 150,000 hectares or on $6 \%$ of the cultivated land in Denmark. Added to the 40 PJ coming from manure etc. these resources could cover up to $9 \%$ of the current energy consumption in Denmark (Skøtt, 2010a). From a production price and crop handling perspective, however, maize would be most attractive, but it requires both fertilizer and pesticides. Grass, especially when grown on natural areas, has several environmental benefits as for instance nitrogen fixation. On the other hand beet both requires fertilizer and pesticides, is difficult to handle, but has the highest yield per hectare (Søndergaard, 2011). It is relatively simple to utilize such types of energy crops in Danish biogas plants in order to increase the gas yield, and is already being undertaken on a small scale. Currently, however, there is a political roof on the amount of energy crops allowed to be used in biogas plants, there is an incentive to produce other solutions not competing with human and animal food in the future (algae).

\subsection{Manure handling ('Resources'; 2020)}

Avoid water mix and methane losses: Until new stables can be built it is important to apply good housekeeping in stables, e.g. to limit the water spills as doing so reduces the dry matter content of the manure. This can, for instance, be achieved by optimizing the use of high-pressure water when cleaning the stables. 
It is often seen that high-pressure water equipment is wrongly adjusted (pressure and performance) which leads to higher water consumption than necessary and thus a lower dry matter content of the manure. Appropriate adjusted drinking cups in stables can also contribute to lower water spills reducing the total water use up to $30 \%$. Lower water content in the manure does not only lead to higher gas yields, but also bring about other benefits such as reducing the need for stirring the manure in reactor tanks by decreasing the energy required to stir the water content, as well as reduced energy needs for heating (Landbrugets Rådgivningscenter, 1996).

Methane losses from manure canals and tanks: Before the manure enters the reactor tank it will be stored for a shorter or longer period, typically 1-2 weeks in manure canals and pre-storage tanks and so forth (though sometimes it may be for much longer periods). Research has recently found methane losses can be up to $36 \%$ at temperatures of $15-20$ degrees $\mathrm{C}$ (this was calculated on the basis of experiments with methane losses during a period of 28 days at different temperatures). It is thus very important to reduce the storage time of manure, especially during warm periods. The methane losses are higher the longer storage time, and even with a temperature of 10 degrees $C$, losses can be quite extensive. At a temperature of 20 degrees $C$ and a storage time of four weeks, the losses would be 150 liter methane $/ \mathrm{kg}$ VS, corresponding to half of the gas potential. Thus, storage of manure in manure canals and pre-storage tanks is an important factor preventing a higher gas yield (Møller, 2010).

\subsection{Extraction of additional gas ('Technology/Conversion'; 2020)} Reactor tanks in series: Given limited gas boosters, all types of options for improving the biogas process must be applied in the short run. This also means extracting as much gas as possible when it reaches the reactor tanks. A large part of the biogas potential in the manure is lost as it passes through the reactors without being fully digested. When fresh manure is added in the top of the reactor tank, the same quantity is extracted from the bottom. This leads to a lack of digestion in existing single reactor plants, as the manure simply runs from the inlet to the outlet at the bottom without being digested. With two or more reactors it is very unlikely that this will be repeated. Experiments have recently shown that the implementation of two reactor tanks in a coupled parallel process can enhance the gas yield by up to $5 \%$. For existing plants already having several reactor tanks, this production enhancement can be applied without notable operation costs and thus it is important for the future economy of the plants (Skøtt, 2010b).

The use of enzymes: Another way of increasing the gas yield from biogas plants operating on a combination of manure and agricultural biomass etc. is to 
add enzymes directly to the process. Enzymes are natural proteins leading to the process of metabolism and are biocatalysts meaning that they are responsible for and cause acceleration in the transformation of organic substances. Enzymes applied to the biogas process can increase the gas yield extensively, indeed up to a $20 \%$ increase in the gas yield from the same amount of raw material has been achieved in certain cases (Zorg Biogas, 2010). In general, however, the effect and cost of adding enzymes is still uncertain and needs further assessment, but could be reachable within the short run. In Denmark research into enzymes for biogas yield enhancement is being undertaken by Novozymes and Danisco.

\subsection{Mixed gas ('Distribution/End-use'; 2020)}

A market expansion for biogas through the natural gas networks is an opportunity that can be exploited within the near future, as the gas networks already exist. This could supplement the existing direct supply of biogas to Danish CHP plants, and make other options for marketing the biogas available for the producers. As mentioned, biogas is used for transportation purposes in Sweden, and distributed in the natural gas networks given the suppliers a better negotiating position, compared to sales to CHP plants only as in the Danish case. The costs of upgrading the biogas to natural gas standards (extracting the $\mathrm{CO}_{2} \& \mathrm{SO}_{2}$ ) are currently too high to make this feasible, but new research shows promising results for a separation technology using amin (a biological decomposable liquid) by which the biogas is 'washed' for $\mathrm{CO}_{2}$ etc. (Skøtt, 2011). Downgrading natural gas to biogas quality could also be an option, reducing the cost connected with upgrading. The drawbacks are that gas boilers in individual houses or industries must be adjusted to the lower gas quality (Tougaard, 2010), and that vehicles need a higher quality gas.

\section{Conclusion}

This paper has discussed how the renewable energy transition capability of the biogas sector can be enhanced to more rapidly move towards a carbon free energy supply. The study combines a Backcasting methodology, which works 'backwards' in time from specific political goals to be reached before 2050 and 2020, with an identification of important research activities based on Energy Chain analysis. Future research activities have thus been identified within the following areas: 'Resources', 'Technology/Conversion' and 'Distribution/End-use'. The paper concludes that by combining the two methodologies a more robust and sustained approach to supporting the future biogas sector can be achieved, being less sensitive to shifting policy regimes with varied focus. Thus, the transition capability of the biogas sector is enhanced, not only by means of applying activities all along the 
energy chain, but also by interconnecting certain activities thus increasing the overall output of future research initiatives. Important research elements are, for instance, to develop additional less competitive biomass as gas boosters, to enhance the biogas process in order to extract more gas, and to develop a low cost turnkey concept, and finally, to increase the market opportunities for selling gas by upgrading the biogas and distribute it on the natural gas network including for transportation purposes. This methodology could very likely be applied to other renewable energy technologies to enhance their transition capability.

\section{References}

AlgeCenter Danmark (2012). Research in AlgeCenter Denmark.

At http://www.algecenterdanmark. dk/. Assessed the 25-12-2012.

Arising (2009). Backcasting. Available at: http://wearearising.org/?S=backcasting. Assessed the 20-11-2012.

Danish Government (2009). Green Growth. Schultz Distribution, Albertslund, Denmark. Danish Government (2008). Energiaftalen af 21. Februar 2008, Copenhagen, Denmark, Available at; Energiaftalen/energiaftale-21022008_final pdf, Assessed the 14-11-2012.

Hamamatsu, T., Saikawa, M., \& Hashimoyo, K. (2004). Energy Chain - A new concept in evaluating future energy conservation and greenhouse abatement alternatives and effectiveness. 19th World Energy Congress. Sydney, Australia, Sept.5-9, 2004.

Klimakommissionen (2010). Grøn energi - Vejen mod et dansk energisystem uden fossile brændsler. Klimakommissionen, Copenhagen, Denmark.

Landbrugets Rådgivningscenter (1996). Håndbog i miljø -og ressourcestyring på Landbrugs-bedrifter. Landbrugets Rådgivningscenter, Skejby, Denmark.

Lovins, A. (1976). Energy strategy: The road not taken? in Foreign Affairs, October 1976.

Lundsgaard, E. (2009). Interview and plant visit at Hashøj Centralized Biogas Plant, Sept., 2009.

Lybæk, R., Christensen, T. Budde, \& Kjær, T. (2012). Biogas technology optimization opportunities: Lessons learned from Denmark, APPEEC Shanghai, Peer reviewed Proceeding, vol. IEEE Catalog nr. CFP12PEE-CDR IEEE.

Lybæk, R., Christensen, T. Budde, \& Kjær, T. (2013). Governing innovation for sustainable development in the Danish biogas sector - An historical overview and analysis of innovation. Forthcoming 2013 in Journal of Sustainable Development, Willer, UK.

Lybæk, R. \& Møller, P. (1999). Teknologisk innovative -og markedsunderstøttede strategier for fremme af gårdbiogasanlæg. Master thesis. University of Roskilde, TekSam, Denmark. 
Ministry of Climate and Energy (2010). National Renewable Energy Action Plan.

Ministry of Climate and Energy, Copenhagen, Denmark.

Møller, H.B. (2010). Husdyrgødning kan give mere gas, in Forskning i Bioenergi (FIB), nr. 34, Dec., 2010.

NSCA; National Society for Clean Air and Environmental protection (2006).

An assessment of the potential role of biogas as renewable transport fuel.

Brighton, UK, ISBN: 0903474611.

Robinson, J.B. (1982a). Energy backcasting - A proposed method of policy analysis, in Energy Policy, Dec., 1982, pp. 337-344.

Robinson, J.B. (1982b). Backcasting into the future - On the methodological and institutional biases embedded in energy supply and demand forecasting, in Technological forecasting and social change. Vol.21, 1982, pp. 229-240.

Robinson, J.B. (2003). Future subjunctive: Backcasting as social learning, in Futures, Vol. 35, 2003, p. 839-856.

Skøtt, T. (2010a). Gylle og energiafgrøder kan dække ti procent af energiforbruget, in Forskning i Bioenergi (FIB), nr. 31, March 2010.

Skøtt, T. (2010b). Fem procent mere gas med to reaktorer, in FIB nr. 31, March 2010. Søndergaard, B. Bastrup (2011). Energiafgrøder - Det rene gas?, in FIB nr. 37, Sept. 2011.

Skøtt, T. (2011). Udgifter til opgradering af biogas kan halveres, in FIB nr. 37, Sept. 2011.

Tougaard, S. (2010). Bedre vilkår på vej for biogas, in Bioenergi Magasinet, nr. 1, Nov.,2010.

Tybirk, K. (red.) (2010). Kogebog for etablering af biogas med 12 faktaark. Agro Business Park / Innovationsnetværket for Biomasse, Skejby, Denmark, Nov., 2010.

Wittrup,

S. (2009), Biogas presset af affaldsmangel, in Ingeniøren, article \# 96991, available at: http:/ /ing.dk/artikel/96991-biogas-presset-af-affaldsmangel, Assessed the 101-2012.

Tafdrup, S. (2009). Biogas presset af affaldsmangel. Sited by Wittrup, S., in Ingeniøren, article \# 96991, available at: http://ing.dk/artikel/96991-biogas-presset-afaffaldsmangel. Assessed the 10-1-2011.

Zorg Biogas (2010), homepage information, at: http:/zorgbiogas.com/regionnews/news_id_3382 full. Assessed the 6-1-2011. 